\title{
Relevance of Vedic Management in Contemporary Times
}

\author{
Aruna Dhamija
}

\begin{abstract}
Vedic management refers to the usage of the knowledge and the invaluable insights as one finds in the ancient Indian scriptures popularly known as Vedas. The knowledge which is to be found in the Vedas is of supreme authority despite being ancient. In fact the veracity of such knowledge has never been more than in the present ages when everything is in the state of constant change. Vedic management precisely deals with such ever-changing scenario in much better manner than many of the so-called modern methods of management. The inscriptions of the Vedas are a school of thought in themselves and when one delves into them much deeper then they leave no doubt in the mind of the seeker that they have answers to all their questions, explicit as well as implicit. The knowledge one gets in the Vedas is esoteric in nature, nevertheless it helps in grasping the significance of the circumstances which one faces in the changing scenario of today's world and more than readies one to face them. The Vedas recognize the importance of the dynamism of the world and its dynamic environment. This paper tries to put into perspective various Vedic concepts which have proven their worth over the course of time as to how one can successfully adjust to and even anticipate change in one's life, both professional and personal (Londhe, 2018). The Vedic literature propagates emancipation of the mankind, both physical as well as spiritual. The paper tries to relate the Vedas with the modern business management principles and practices. This paper goes on to highlight how one can benefit immensely be practicing the various Vedic concepts to come out of the changing paradigms in a never-before way. This is made possible because of the veracity of the Vedas, because of the simple fact that Vedas have been an incessant source of wisdom and sagacity which has withstood every test of time and which has proven, time and again, that no matter how old the knowledge is, what matters is how good a person is in interpreting and utilizing it. Thus, the Vedas encourage one to face the unknown facets of life, howsoever difficult they are, with much ease and assuredness and that is the theme of this paper which would put together the significance of Vedic Management and its subsequent impact of managing change in today's world of clutter, confusion, chaos and competition.
\end{abstract}

Keywords : Circumstances, Confusion, Clutter, Vedas.

\section{INTRODUCTION}

The Vedas, an ancient scripture highlighting the high point of Hinduism and its astuteness, comprise of four constituents namely Rig Veda, Sama Veda, Yajur-Veda, and Atharva Veda. Each of these four Vedas has four parts consisting of hymns, rituals, theologies and philosophies. These scriptures have some path breaking thought processes on the various aspects of life and how they are to be dealt with. Veda is a Sanskrit word which is derived from the root word 'vid' meaning knowledge.

Revised Version Manuscript Received on 16 September, 2019. * Correspondence Author

Dr Aruna Dhamija, Professor, Institute of Business Management, GLA University, Mathura, India.
The Vedas are some of the most ancient texts. The origin of these scriptures dates back to $1500-1000 \mathrm{BC}$. The period is generally called the Vedic period and it spanned through some parts of Bronze Age and the Iron Age collectively. They form the basis of 'Sanatana Dharma' followed by Hindus.

Vedic management refers to the usage of the knowledge and the invaluable insights as one finds in the Vedas (Kannan, 2009). The knowledge which is to be found in the Vedas is of supreme authority despite being ancient. In fact the veracity of such knowledge has never been more than in the present ages when everything is in the state of constant change.

Vedic management precisely deals with such ever-changing scenario in much better way than many of the so-called modern methods of management. The inscriptions of the Vedas are a school of thought in themselves and when one delves into them much deeper then they leave no doubt in the mind of the seeker that they have answers to all their questions, explicit as well as implicit.

The knowledge one gets in the Vedas is sometimes esoteric in nature. Nevertheless, it helps in grasping the significance of the circumstances which one faces in the changing scenario of today's world and more than readies oneself to face them. The Vedas recognize the importance of the dynamism of the world and its ever-changing environment.

Various Vedic concepts have proven their worth over the course of time as to how one can successfully adjust to and even anticipate change in one's life, both professional and personal. The Vedic literature propagates emancipation of the mankind, both physical as well as spiritual.

\section{VEDAS: RELEVANCE IN MODERN TIMES}

When one talks about Vedic Management, it is often wondered what the relevance of such an old concept is in today's modern times? People might have this notion that such a concept might not be fit for the scientifically oriented and result-driven population. Nothing can be farther from truth. This is so because when we talk about Vedic Management, we invariably talk about scientific management because whatever is Vedic is, in turn, scientific. That is to say if anything has to be mathematically precise, it has to be Vedic. If anything has to exhibit evolutionary features and has to be path breaking in nature, it has to be Vedic. You need to look no farther than Swami Vivekananda who derived much of his knowledge and wisdom from these reservoirs of eternal sagacity. The power of such wisdom was accepted and acknowledged by the so-called advanced Western society way back.

To cut a long story short, anything that has anything to do with being progressive it has to be Vedic. Such is the level of pragmatism which one can associate with the Vedas and subsequently Vedic 
Management. In fact, Vedic Management is something which upholds everything. That is to say, all the modern theories of science corroborate the theory of Vedic Management thus leaving not much scope for the skeptics who might not see much of worth in the applicability of Vedas and their depth in virtuosity which is not the case. It is just the opposite to it.

Vedic Management is all about objectivity. Either you possess it or you not. Such is the preciseness of it that even the modern principles of science seem to derive their objective-oriented approach from it. All the laws which man has known since times immemorial have an association or derivation from the management as envisaged from the Vedas. The knowledge derived from Vedic Management is reliable, executable, interpretable, understandable, and result-driven and has much riding on to it. Vedic Management doesn't talk in terms of ifs and buts rather it talks in terms of what if, a classic case of scientific rationality. In all, it is quite difficult even for the die-hard critics of Vedic Management to find much fault with its veracity.

Vedic Management transcends the limitedness of the various disciplines of knowledge. This is so because it is for all and all for Vedic Management. It derives its acceptance from this simple fact that traces of knowledge emanating from Vedas is to be found in every possible field of knowledge, no matter how varied they are. The perfection which one finds in Vedic Management is unmatched and is further substantiated from the fact that all the paradigms of management derive their notion of perfection from it to a large extent.

\section{MODERN BUSINESS PRINCIPLES AND PRACTICES VIS-À-VIS VEDAS}

The Vedic Management principles cover a large gamut of areas, the area of modern business being one of them. The principles of business, as one views today, are very much in tandem with the Vedas and the Vedic Management principles and preaching are to be found in abundance and frequently in them. In all of the human endeavours which imbibe the various management principles, the pervasiveness of Vedas is highlighted and is hard to miss. The relevance of such esoteric manuscripts in modern day principles is indeed something which baffles many and it is because of this fact that the importance of Vedas has gone only one direction - north. The holistic approach which one normally associates with the Vedas is amply reflected in the principles of management when one talks about the appropriateness of them. Such modern day business principles as planning, organizing, leadership, self-assuredness, motivational ability, coordination, cooperation, unity, communication, control as well as a host of other immensely popular concepts find their mention in these ancient manuscripts.

For a company to create wealth for its various stakeholders, it becomes very important that it plays its cards well. Sticking to the fundamentals, doing the right things at the right times, taking the right path howsoever tortuous it might be, are some of the practices which ensure the success of any firm. Warren Buffet, founder of Berkshire Hathaway and one of the richest men in the world, still does things in the good old ways and comes out a winner as against the proponents of modern practices of doing business. What instead is to be understood is that if your fundamentals are right you will never be caught off guard. This is the sheer beauty of the Vedas and their role in managing the changing paradigms of business. Vedas are astute in their view of business practices and mention in much description the varied roles played by individuals if one is expected to do good on the professional front. The Vedas are not immune to such concepts as wealth creation, retention and maximization thus putting to rest any doubts that they are not fit as modern day guide.

Next, Vedas are an imminent source of knowledge and its management. As long as one is having knowledge that is timely and relevant, it is easy to remain ahead of others. It is indeed challenging to understand the real source of knowledge more so given the fact that knowledge exists in both tacit and explicit forms (Bose, 1970) Vedas put great emphasis on acquisition and usage of relevant and timely knowledge which liberates a person and makes him effective as well as efficient. Vedic Management highlights the certainty aspect and promulgates that whenever there is definitiveness, proper dissemination and utilization of knowledge is possible.

What is to be understood here is the simple fact that Vedas need you to understand - It is never the wrong time to do the right thing and it is never the right time to do the wrong thing!

\section{RELATING VEDAS WITH CHANGE}

As is well said and understood: the only thing permanent is change! Carrying forward this maxim, one can safely assume that change is something with which we have to accustom ourselves on a day-to-day basis.

Change is something which one identifies with normalcy. That is to say, if everything is static we wonder if everything is alright! Such is the significance of change in life. Only those excel in today's tasking times, who stay ahead of others by changing themselves and their institutions before others do.

The optimists are those change leaders who see change as an opportunity to prove themselves and in this regard managing change and in effect leading change becomes the crux. Winner is the one who knows the right change, the right time to introduce it, the right way to introduce it, the right people to introduce it and the right tools for the same.

Vedas provide as the guide force which one can resort to when dealing with change. Vedas act as the eternal source of wisdom and sagacity to which one can look up to come out with innovative ways so as to introduce change in an amicable way.

\section{LEADING CHANGE: THE VEDIC WAY}

Vedas have been an eternal source for those seeking enlightenment in the various aspects of life. When it comes to as to how one is expected to behave in the changing scenario, Vedas have been more than successful in explaining the ramifications and throwing light on the possible alternatives which one might resort to when in a state of flux (Parthasarthy, 1978). For ages, Vedas have been proponents of equality, that is, meting out a treatment of equal importance for those doing work of equal significance without discriminating on any grounds. Such practices are yet to be adopted fully but one finds their mention in the Vedas. What is this if not leading the change!

The Vedas lay great emphasis on managing one's human resources in the best possible way because they have made it amply clear that it is the people who are most important and to

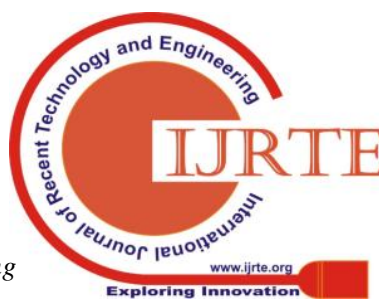


come think of it that we are talking of manuscripts thousands of years old. What better example we can have for change and its subsequent and effective management?

The Vedas have been at the forefront in highlighting the fact that no two people are alike and as per their persona one should decide what work should be carried out by whom. This amply highlights the vision of those who wrote such enlightening manuscripts.

Such modern day practices as labour welfare have been mentioned in the Vedas. What better way to highlight the progressiveness of any society or organization than to see how clear they are regarding their succession plan which is to put an effective second line of managers! Here also Vedas have been showing the light all the way along. Relationship management is considered to be of utmost importance in today's times and Vedas have been very clear about how significant they are.

The concept of Corporate Social Responsibility which we try to highlight as often as we can as an effective Public Relations tool has its proponent in those who wrote these wonderful scriptures.

The buck doesn't stop here. All that you can think in terms of fair practices such as protection of poor, equality, social obligations, sponsorship, rejecting the wrong doers find mention in these books. Social distribution of wealth, a cause so endeared by the socialists does find a mention in these wondrous books.

Such modern day concepts like conservation, non-pollution, environment protection, time management, quality management, corporate governance, change management, productivity management, globalization, competition management, women leadership, self-management, benchmarking, cultural perspectives, ethics and values find place in these manuscripts.

We are yet to come across any other written manuscript which were as future-ready as are Vedas and rightly so. The role which they have played in shaping up the traditional society provides us with the reasons why India used to be the wealthiest nation before the country was invaded by the foreigners, especially the British who had the least of regard for our culture and heritage. They ensured the downfall of our culture and propagated and imposed Western beliefs on us which we lapped up happily without thinking about the consequences. Had we stick to our roots, the result would have been much different. Cases in point, the Chinese, majority of the Europeans and the Japanese who lead the world today without having left their legacy and ancient learning.

\section{RESULT}

As a result, we find that with the help of such learning from this manuscript which would help in reclaiming the position which we once foregone to the outsiders.

It would take lot of work on the part of the society and its various institutions to understand the significance of Vedas and the theories as propounded by them and to inculcate such practices and principles in day-to-day functioning of their respective institutions.

Therefore, we can say that the Vedas inspire one to face the unknown facets of life, howsoever difficult they are, with much ease and assuredness.

\section{CONCLUSION}

So what is needed to be done? The need of the hour is to lap up the principles, practices, preaching, and other aspects which one finds in these scriptures and make them the beacon of light which would guide us in the times to come thus leading us to change in the best possible way. We can endorse and imbibe such learning from these manuscripts which would help in reclaiming the position which we once foregone to the outsiders. However, it is easier said than done. It would take lot of work on the part of the society and its various institutions to understand the significance of Vedas and the theories as propounded by them and to inculcate such practices and principles in day-to-day functioning of their respective institutions. To start with, all the concurrent practices and principles which are a reflection of the changing paradigms such as those mentioned several times in this paper should be grasped and taken care of by them so that a beginning is made.

This paper goes on to highlight how one can benefit immensely be practicing the various Vedic concepts to come out of the changing paradigms in an unprecedented way. This is made possible because of the veracity of the Vedas, because of the simple fact that Vedas have been an incessant source of wisdom and sagacity which has withstood every test of time and which has proven, time and again, that no matter how old the knowledge is, what matters is how good a person is in interpreting and utilizing it.

Thus, we can say that the Vedas encourage one to face the unknown facets of life, howsoever difficult they are, with much ease and assuredness. Vedic Management helps in managing change in today's world of clutter, confusion, chaos and competition. It provides you with the right way of meandering through the various phases of life, prepared for the changes which one can anticipate as a result of Vedic Management. The Vedas talk about conscientiousness, what is wrong what is right, our conscience. So if we need to excel in life, we need to ace all the changes in our life then we need to embrace the Vedic way of life in more ways than one. When we say embrace Vedic way of life, we are not resorting to endorsing cramming the Vedas. Rather what is implied is simply follow what is right and the rest will follow automatically! Such is the clout of Vedas, such is the following they ought to enjoy. But the days are not far when change would be synonymous with the various facets of Vedas.

As the Vedas include so many relevant and time-defying concepts unto themselves, it would be unwise on part of the people of today to underestimate their significance in guiding them through the various aspects of change and to lead them in such terrains which are unexplored, waters that are untested, concepts which are unexplained. Such is the magnitude of Vedic Management that it has the supremacy to lead all such phenomena which one very much needs in the changing circumstances.

As Swami Dayanand Saraswati famously said, "Back to Vedas"!! 
Relevance of Vedic Management in Contemporary Times

\section{REFERENCES}

1. Kannan, S, (2009).Vedic Management, Taxmann Publications, New Delhi

2. Sastri, G. A History of Vedic Literature, Sanskrit Pustak Bhandar, Kolkata

3. Bose, A.C. (1970) in Munshi, K.M. and Diwakar, R.R. (Eds), The Call of the Vedas, BharatiyaVidya Bhavan, Bombay, pp. 249, 244

4. Londhe, M. (2018, May). Vedic Concept of Rta: The Cosmic Order. In Proceedings of the XXIII World Congress of Philosophy (Vol. 16, pp. 143-148).

5. Parthasarthy, A. (1978). Vedanta Treatise, Vedanta Life Institute, Mumbai

6. Ranganathananda, Swami; Democratic Administration in the Light of Practical Vedanta, Sri Ramakrishan Math, Chennai

7. Macdonell, Arthur; A Vedic Reader for Students, Oxford University Press, Chennai

8. Srinivasacharya, K S; An Introduction to the Vedas, The Alliance Company, Chennai 